\title{
ASSESSMENT OF CALCIUM AND VITAMIN D CONTENT IN MEALS SERVED FOR PRESCHOOL CHILDREN ATTENDING TO KINDERGARTENS IN SOME SILESIAN CITIES
}

\author{
Marek Strobal, Jolanta Malinowska-Borowska ${ }^{2}$
${ }^{1}$ Medical University of Silesia, Faculty of Health Sciences, Scientific Club at Department of Toxicology and Health Protection, 18 Piekarska Street, 41-902 Bytom, Poland 18 Piekarska Street, 41-902 Bytom, Poland \\ ${ }^{2}$ Medical University of Silesia, Faculty of Health Sciences, Department of Toxicology and Health Protection,
}

\begin{abstract}
Background. Adequate nutrition is one of the most important factors for influencing growth and development of children. Providing adequate amounts of minerals is extremely important in the developmental age, especially in periods of intensive growth. Calcium and vitamin D deficiency may have a negative impact on the health of children, both in the short and long term.

Objective. The aim of this study was to evaluate the content of calcium and vitamin D in the meals of preschoolers and to compare the obtained results to Polish dietary reference values for children aged 4-6 years.

Material and methods. The study was conducted in 40 randomly selected kindergartens in some Silesian cities and were concerning 1,746 children. 10-day-menus and preschool inventory reports describing the amount of food used for meal preparation were obtained from every kindergarten. 10-day-menus were analysed in terms of calcium and vitamin D content with the use of the Dieta 5 software. The obtained results were developed in Microsoft Excel 2016.

Results. The analysis of 10-days menus showed significant deficiencies in both calcium and vitamin D intake in the assessed food rations. The mean calcium level was $416.0 \mathrm{mg}$ while vitamin $\mathrm{D}$ was $1.47 \mu \mathrm{g}$. The content of calcium and vitamin $\mathrm{D}$ in the examined 10-days menus did not meet the dietary reference values.

Conclusions. The necessity to modify menus in terms of increasing the consumption of the analysed nutrients was demonstrated, as well as the need to implement nutritional education for preschool staff and parents was suggested.
\end{abstract}

Key words: children's nutrition, vitamin D, calcium, menu, kindergarten, preschool children

\section{STRESZCZENIE}

Wprowadzenie. Prawidłowe odżywianie jest jednym z najważniejszych czynników warunkujących prawidłowy wzrost i rozwój dzieci. Dostarczanie odpowiednich ilości składników mineralnych ma istotne znaczenie w wieku rozwojowym, a zwłaszcza w okresach intensywnego wzrastania. Niedobór wapnia oraz witaminy D może wpływać negatywnie na stan zdrowia dzieci zarówno doraźnie jak i długofalowo.

Cel. Celem niniejszej pracy była ocena zawartości wapnia i witaminy D w posiłkach przedszkolaków oraz porównanie uzyskanych wyników z normami żywienia dla dzieci w wieku 4-6 lat.

Materiał i metody. Badanie zostało przeprowadzone w 40 losowo wybranych placówkach przedszkolnych w miastach aglomeracji śląskiej i dotyczyło 1746 przedszkolaków. W każdej z placówek uzyskano raporty magazynowe i jadłospisy dekadowe. Ocenę zawartości wapnia oraz witaminy D przeprowadzono na podstawie jadłospisów dekadowych wykorzystując program Dieta 5. Uzyskane wyniki zostały opracowane w programie Microsoft Excel.

Wyniki. Analiza jadłospisów dekadowych wykazała znaczne niedobory w spożyciu zarówno wapnia jak i witaminy D w ocenianych racjach pokarmowych. Średni poziom wapnia wynosił 416,0 mg podczas gdy witaminy D 1,47 $\mu \mathrm{g}$. Zawartość wapnia oraz witaminy D w badanych jadłospisach dekadowych nie spełniała obowiązujących norm żywienia. Wnioski. Wykazano konieczność modyfikacji jadłospisów pod kątem zwiększenia spożycia analizowanych składników odżywczych, a także zasugerowano potrzebę wdrażania edukacji żywieniowej personelu przedszkolnego oraz rodziców.

Słowa kluczowe: $\dot{z} y w i e n i e ~ d z i e c i$, witamina D, wapń, jadłospis, przedszkole, przedszkolaki

Corresponding author: Jolanta Malinowska-Borowska, Medical University of Silesia, Faculty of Health Sciences, Department of Toxicology and Health Protection, 18 Piekarska Street, 41-902 Bytom, tel. +48 601062777, e-mail: jmalinowska@sum.edu.pl

(C) Copyright by the National Institute of Public Health - National Institute of Hygiene 


\section{INTRODUCTION}

Adequate nutrition of preschool children plays a key role in the development of the body. A properly balanced diet that provides the necessary nutrients supports the harmonious physical and mental development of the young organism. In the preschool age, eating habits are formed. Family environment and parents play a significant role in dietary patterns and eating behaviours [1]. It depends on parents how the nutritional models in children will develop in the future. Inadequate nutrition of a preschool child is associated with an increased risk of diet-related diseases such as diabetes, cardiovascular diseases, bone and joint diseases and cancer. In addition, improper diet results in weight gain, which may lead not only to obesity, but also to eating disorders and the appearance of depression symptoms in adolescence [2] .

For the proper psychophysical development of a child, in addition to the appropriate content of energy, proteins, fats and carbohydrates, it is necessary to meet the applicable dietary reference values for vitamins and minerals. Calcium and vitamin D are particularly important for the proper development of a child.

Vitamin D and calcium have a multidirectional effect on the human body. Calcium and vitamin D are involved in the regulation of calcium and phosphate metabolism, they affect the proper development of the child's skeletal system until the end of the growth period. Calcium deficiency in children causes rickets and insufficient growth, which may result in an increased risk of osteoporosis in the future. This element is essential for maintaining proper blood clotting, which influences the wound healing process. Calcium is essential for the proper functioning of the nervous and muscular systems and plays important role in the electrical activity and pumping function of the heart [3, 4].

Milk and its products, canned fish (sardines), which are eaten with bones are easily accessible calcium-rich food. Some vegetables, e.g. wheat bran, parsley, kale, almonds are also a good source of calcium. Vitamin D is found primarily in oily sea fish, such as mackerel, herring and salmon. Plant products and fungi contain small amounts of vitamin D [5].

According to the review of the studies on nutrition in Polish preschool children there was no kindergarten in which meals served for children contained adequate amount of vitamin D [6]. Moreover, preschool inventory reports describing the amount of food were analysed in few Polish papers only [7].

The aim of the study was to evaluate 10-day menus and inventory reports in kindergartens in Silesian cities with regard to the content of calcium and vitamin $\mathrm{D}$. The obtained results were compared with the applicable dietary reference values for the Polish population in preschool age.

\section{MATERIAL AND METHODS}

From among 373 kindergartens, 50 institutions were randomly selected as a research sample. 10 kindergartens refused to participate in the study. Ultimately, 40 kindergartens with a total of 1,746 children, were recruited for the study. Kindergartens participating in the study, shared 10-days menus and preschool inventory reports with amount of food used for preparing meals. The Table 1 presents the number of kindergartens in cities, where menus and preschool inventory reports were collected.

Table 1. Number of kindergartens participating in the study $(n=40)$

\begin{tabular}{|c|c|}
\hline City & $\begin{array}{c}\text { Number } \\
\text { of kindergartens }\end{array}$ \\
\hline Bytom & 5 \\
\hline Chorzów & 2 \\
\hline Dąbrowa Górnicza & 3 \\
\hline Jaworzno & 1 \\
\hline Katowice & 8 \\
\hline Mysłowice & 2 \\
\hline Piekary Śląskie & 3 \\
\hline Gliwice & 2 \\
\hline Ruda Śląska & 4 \\
\hline Siemianowice Śląskie & 2 \\
\hline Sosnowiec & 2 \\
\hline Tychy & 2 \\
\hline Zabrze & 4 \\
\hline total & 40 \\
\hline
\end{tabular}

Most menus came from institutions in Katowice, which accounted for $20 \%$ of all kindergartens participating in the study $(\mathrm{n}=8)$. Kindergartens from Bytom (12.5\%) were second in terms of frequency. Only 1 kindergarten was from Jaworzno.

The content of calcium and vitamin D was calculated on the basis of preschool food storeroom reports with amount of food used. The obtained amount of food products included in a given meal was divided by the number of children who participated in it.

All kindergarten canteens used a cycle menus. Hence, 10-day menus were assessed in each of 40 kindergartens. Dieta 5 software was used to assess energy intake, content of individual components (proteins, fats, carbohydrates) and the content of calcium and vitamin D in the food ration. Due to the temperature sensitivity of vitamins, food losses 
appropriate for a given technological treatment, were taken into account. Then all values were summed up. In this way, the average levels of calcium and vitamin $\mathrm{D}$ and additionally assessed food components were estimated. Next, the obtained results were compared with the current dietary recommendations for children aged 4-6 years. The intake of calcium was compared to EAR (Estimated Average Requirement) while the vitamin D to AI (Adequate Intake) defined in Dietary Reference Intakes for the Polish Population [8]. The daily intake of cholecalciferol in $\mu \mathrm{g}$ per day for children aged 4-6 years is $15 \mu \mathrm{g}$, while the daily intake of calcium is $800 \mathrm{mg}$ per day [8].

To assess the diet of children aged 4-6 years, weighing $19 \mathrm{~kg}$ and characterised by moderate physical activity, the daily energy intake of $1400 \mathrm{kcal}$ was adopted in accordance with the recommendations [8]. The energy and nutrient content of the preschool menus was compared to $75 \%$ of the daily requirement for children aged 4-6 years [9]. According to this, the recommended value for energy was $1050 \mathrm{kcal}$ [8].

\section{RESULTS}

In 400 analysed menus, the daily food ration, meaning meals served only in kindergarten, consisted mainly of three meals (breakfast, lunch, afternoon tea). In 30 kindergartens a system of three meals a day was used. Every fourth institution served four meals. The energy value and the content of individual components (proteins, fats, carbohydrates) in the daily food ration were analysed. The energy value of menus in the analysed Silesian kindergartens ranged from 821-1489 kcal. Among the 40 kindergartens which participated in the study, there were menus that did not fully meet the energy needs of children aged 4-6 years. Some children received insufficient calories, others received too much calories compared to the recommended values for the 4-6 year old population. The average energy value of the diet was $1122.35 \mathrm{kcal}$. A summary of the average energy values of various kindergartens in Silesian cities is presented in Figure 1.

The analysis of the obtained results showed a reduced energy value in kindergartens in Ruda Śląska and Siemianowice Śląskie. In Bytom, Sosnowiec and Katowice the average energy value was close to dietary reference intake recommended for Polish population. The mean value of protein, fats and carbohydrates was $36.5,39.6$ and $155 \mathrm{~g}$ respectively.

The mean content of calcium based on 10-days menus was $416 \mathrm{mg}$, which was $52 \%$ of the daily food ration. The highest amount of vitamin $\mathrm{D}$ was recorded in the kindergartens in Bytom, namely $3.30 \mu \mathrm{g}$. It accounted for only $22 \%$ of the entire daily food ration. The smallest amount of vitamin D was consumed by children attending kindergartens in Chorzów and Jaworzno. The distribution of calcium and vitamin D content in meals served for preschool children in Silesian cities is shown in Figures 2 and 3.

In this study, large differences in the content of calcium and vitamin $\mathrm{D}$ were observed in kindergartens. The usual calcium intake was insufficient in most institutions (97\%). It was shown that 16 kindergartens $(40 \%)$ covered only half of the recommended supply for calcium.

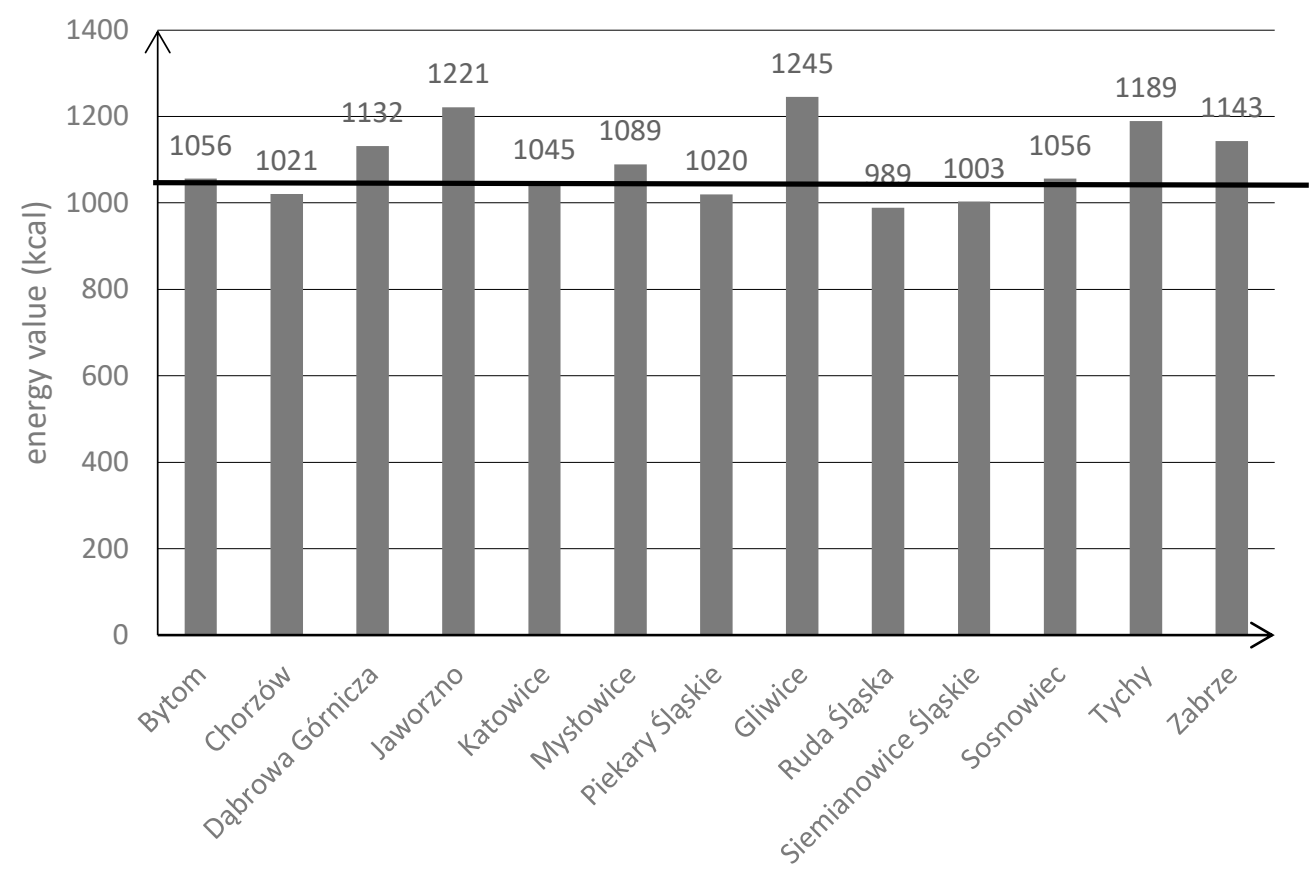

Figure 1. A summary of average energy values in diets in kindergartens participating in the study in Silesian cities (1050 $\mathrm{kcal}$ is the recommended value assumed as $75 \%$ of dietary reference energy intake) 


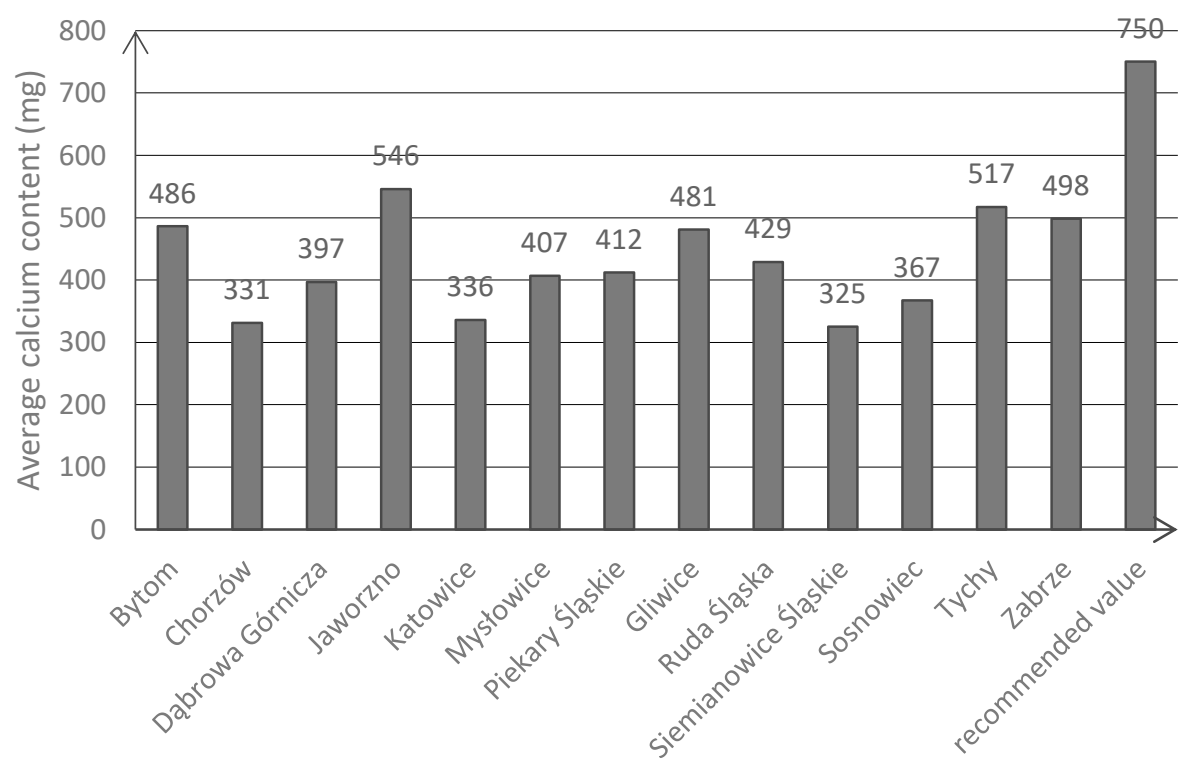

Figure 2. Average calcium content in daily menus in kindergartens $(n=40)$

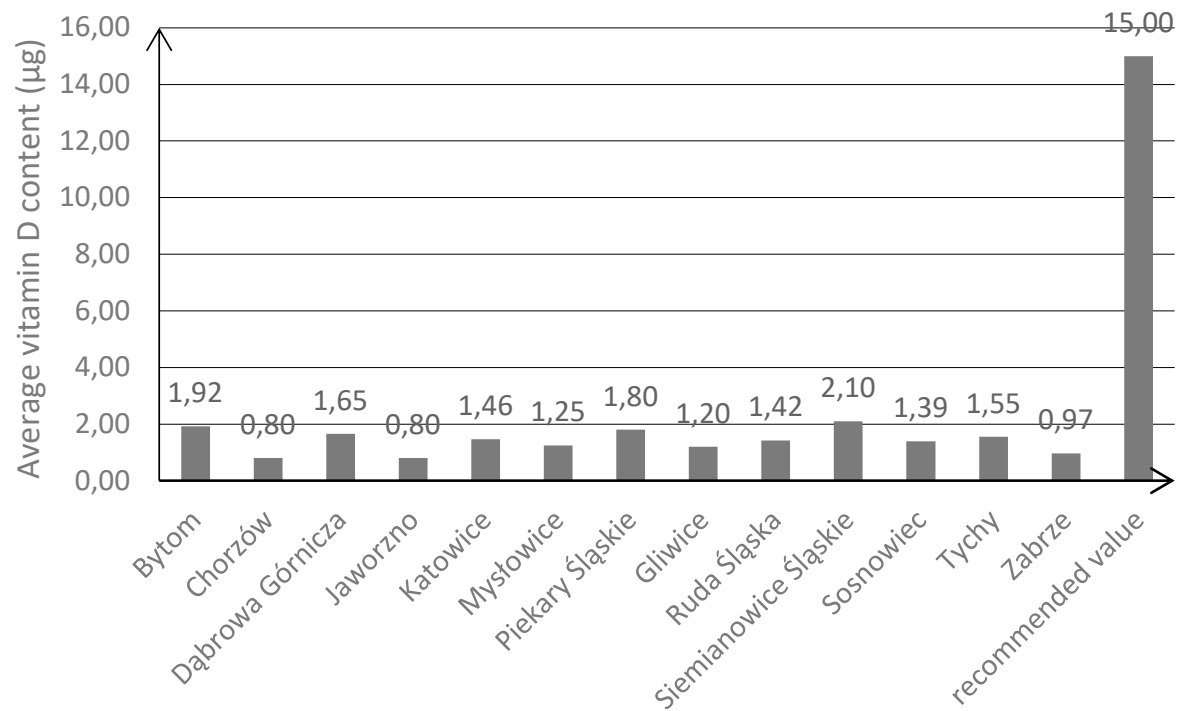

Figure 3. Average vitamin D content in daily menus in kindergartens $(n=40)$

Table 2. Energy value, calcium and vitamin D content in the diets realised by kindergartens

\begin{tabular}{|c|c|c|c|c|c|}
\hline & Mean value & $\begin{array}{c}\text { Standard } \\
\text { deviation }\end{array}$ & Minimum & Maximum & $\begin{array}{c}\% \text { of standard } \\
\text { fulfillment }\end{array}$ \\
\hline Energy value $(\mathrm{kcal})$ & 1122.35 & 160.57 & 821 & 1489 & 106 \\
\hline Calcium $[\mathrm{mg}]$ & 416.0 & 122.97 & 196.0 & 832.0 & 52 \\
\hline Vitamin D $(\mu \mathrm{g})$ & 1.47 & 0.61 & 0.60 & 3.30 & 9.8 \\
\hline
\end{tabular}

Similar results were found in the case of vitamin D. In $40 \%$ of kindergartens, the intake of vitamin D ranged from $0.75-1.25 \mu \mathrm{g}$. Only 2 kindergartens achieved a result above $2.75 \mu \mathrm{g}$. The maximum value was $3.30 \mu \mathrm{g}$ (Table 2).

\section{DISCUSSION}

The quantitative analysis of food rations in kindergartens in Silesian cities indicate nutritional mistakes in the preparation of menus for children aged 4-6 years. Researches by other authors analysing menus in kindergartens also confirm irregularities in 
meeting the demand for calcium and vitamin D by children aged 4-6 years.

In this research, the average calcium intake was $416.6 \mathrm{mg}$ per day, which is $52 \%$ of the average dietary reference intake of calcium (EAR) that should be provided by a preschool. Out of 40 analysed kindergartens, only one institution covered the demand for calcium in full.

The study found that most institutions do not meet the requirements of this key element in menus of preschool children. Other authors also report an insufficient supply of calcium in children's diets. In the study by Orkusz and Wlodarczyk, concerning the nutrition of children in one of the kindergartens in the Łódź Province assessed with the use of decade menus, the average calcium consumption was $381.55 \mathrm{mg}$ [10].

In the work of Merkiel and Chalcarz, the intake of minerals by preschool children from Turek was analysed [11]. The 7-day menu was analysed and compared to the EAR recommended values for this age-group. According to the findings, the average calcium value was $518 \mathrm{mg}$.

Slightly higher calcium intake was obtained in another study realised among pre-school children in Koszalin [12]. Menus from 3 decades in the spring and summer season were analysed. The food ration consisted of 3 meals, breakfast, snack and a twocourse dinner, and was established as a $70 \%$ of the daily requirement. The preschool children used to eat afternoon snack and supper at home. The average calcium was $578.7 \mathrm{mg}$ and it was accounted for about $82 \%$ of the recommended intake [12].

Completely different results were obtained in another study, where the nutrition of children on a ovo-lacto-vegetarian diet in kindergarten was assessed [13]. This diet eliminates the consumption of meat, fish and seafood, while accepting, apart from fruit and vegetables, milk and dairy products, honey and eggs [14]. As in the previous work, it was assumed that the daily food ration is equal to $70 \%$ of the daily requirement. According to analysed menus, the average calcium value was $946 \mathrm{mg}$, which was about $135 \%$ of the current dietary recommendation.

Charzewska and Weker [15] are of a similar opinion, as they analysed the diets of 400 preschoolers in nationwide studies on the content of calcium and vitamin $\mathrm{D}$ in the diets of 4-year-old children. There was a seven-day record for mothers and a five-day record for kindergarten teachers. It was found that the diets of $51 \%$ of children are chronically deficient in calcium [15]. The unexpected low calcium intake is shocking due to the fact that for years in Poland the consumption of dairy products by children has been promoted. It has been possible to hear about the influence of calcium on bone growth, for example, from advertising spots for dairy products shown on TV.
In our own work, the average consumption of vitamin $\mathrm{D}$ was $1.47 \mu \mathrm{g}$, which is less than $10 \%$ of the AI reference values. Assuming that a preschool institution realizes $75 \%$ of the daily food ration, the obtained calcium value constitutes $13 \%$ of the dietary reference intake. None of the 40 analysed kindergartens in Silesian cities fully covered the demand for this vitamin.

Similar results as in our own work were presented in other papers. The average intake of vitamin D in the analysed menus in Turek oscillated around $1.48 \mu \mathrm{g}$ [11]. In the above-mentioned study by DymkowskaMalesa and Szparaga, in which the amount of selected vitamins and minerals in preschool food rations was assessed, an average vitamin D value of 1.18 $\mu \mathrm{g}$ was obtained [12]. Assuming that the preschool food ration should constitute about $70 \%$ of the daily standard it was $11.23 \%$ of the recommended level [12]. Three decade menus were assessed and none of them provided preschoolers with an adequate supply of this vitamin. In a kindergarten with a ovo-lacto-vegetarian diet, the consumption of vitamin D was $1.96 \mu \mathrm{g}$ and accounted for $18.67 \%$ of the RDA [13].

In our study the average energy value of the diet was $1122.35 \mathrm{kcal}$ and it was higher than the recommended value for preschool children, which should be 1050 kcal [8]. Excess calories consumed increases the risk of overweight or obesity. If this condition persists in childhood, the risk of obesity in adulthood increases [16].

In our study, apart from the analysis of calcium and vitamin $\mathrm{D}$ in the diets, the consumption of basic nutrients was also calculated: proteins, fats and carbohydrates. There were irregularities in the excessive consumption of proteins, which accounted for $111.11 \%$ of the recommended values. The presence of fats was also above the recommended value and amounted $104.49 \%$. The ingredient that was present in an appropriate amount for children aged 4 - 6 were carbohydrates $(98.41 \%$ of the proposed recommendations).

Daily food ration consisted of 3 meals (breakfast, dinner, afternoon snack) in 30 analysed kindergartens. In the remaining 10 institutions, full board included 4 meals (breakfast, elevenses, lunch, afternoon tea). Eating more meals did not increase the intake of calcium or vitamin D. As an additional ration, a snack in the form of fruit, sponge cakes or biscuits predominated.

\section{CONCLUSIONS}

The quantitative analyses of food rations carried out in kindergartens in Silesian cities indicate nutritional mistakes in the preparation of menus for children aged 4-6 years. The average calcium and vitamin D 
content do not meet the recommended values for this age group so children can be at risk of calcium and vitamin D deficiency. Parents should consider vitamin D supplementation.

\section{Conflict of interest}

The authors declare no conflict of interest.

\section{REFERENCES}

1. de Castro J.M.: Heredity influences the dietary energy density of free-living humans. Physiol Behav. 2006;87(1):192-8.

2. Sosnowska-Bielicz E., WrótniakJ.: Nawyki żywieniowe a otyłość dzieci w wieku przedszkolnym i szkolnym. [Nutritional habits and obesity in preschool and school-age children] Lubelski Rocznik Pedagogiczny 2013;32:147-165 (in Polish).

3. Dittfeld A., Gwizdek K., Koszowska A., Fizia $K .: \quad$ Wielokierunkowe działanie witaminy D. [Multidirectional action of vitamin D] Annales Academiae Medicae Silesiensis 2014;68(1): $47-52$ (in Polish).

4. Zdrojewicz Z., Chruszczewska E., Miner M.: Wpływ witaminy D na organizm człowieka [The effect of the vitamin D on the human body] Med Rodz 2015;2(18):6166 (in Polish).

5. Kunachowicz H., Nadolna I., Przygoda B., et al.: Tabele składu i wartości odżywczej żywności [Tables of the composition and nutritional value of food], Wydawnictwo Lekarskie PZWL, Warsaw, 2017 (in Polish)

6. Merkiel S., Chalcarz W.: Review of the studies on nutrition in Polish preschool children. Part 1. Preschool menus. Rocz Panstw Zakł Hig 2016;67(3):223-235

7. Merkiel-Pawtowska S., Chalcarz W.: Review of the studies on nutrition in Polish preschool children. Part 2. Meals prepared at preschool. Rocz Panstw Zakł Hig 2017;68(1):15-21

8. Jarosz M., Rychlik E., Stoś K., Charzewska J. (eds.): Normy żywienia dla populacji Polski i ich zastosowanie. [Dietary reference intakes for Polish population and their application], NIZP-PZH, Warsaw, 2020 (in Polish)

9. Cichocka A.: Przykładowe jadłospisy na 10 dni dla dzieci w wieku 4-6 lat; śniadanie - obiad - podwieczorek $(\sim$ $1050 \mathrm{kcal}, 75 \%$ dziennego zapotrzebowania). [Sample menus for 10 days for children aged 4-6; breakfast - lunch - afternoon tea $(\sim 1050 \mathrm{kcal}, 75 \%$ of the daily food ration)] in Charzewska $J$. (ed): Jadłospisy dla dzieci w wieku przedszkolnym (śniadania, obiady, podwieczorki) opracowane zgodnie $\mathrm{z}$ zasadami prawidłowego żywienia, Wydawnictwo IŻŻ, Warszawa, 2011 (in Polish)

10. Orkusz A., Wtodarczyk A.: Ocena żywienia dzieci w przedszkolu na podstawie dekadowych jadłospisów. [Assessment of the nutrition of children in kindergarten on the basis of decade-long menus] Nauki Inżynierskie i Technologie 2014;1(12) (in Polish).

11. Merkiel S., Chalcarz W.: Analiza spożycia składników mineralnych przez dzieci $\mathrm{w}$ wieku przedszkolnym $\mathrm{z}$ Turku. [Analysis of the consumption of minerals by preschool children from Turek]. Med Rodz 2016;1(19):713 (in Polish).

12.Malesa-Dymkowska M., Szparaga A.: Ocena spożycia wybranych witamin i składników mineralnych w przedszkolnych racjach pokarmowych dzieci z terenu Koszalina [Assessment of the consumption of selected vitamins and minerals in preschool food rations of children from Koszalin]: Nowa Pediatr 2013/03 (in Polish)

13. Malesa-Dymkowska M., Szparaga A.: Ocena żywienia dzieci pozostających na diecie laktoowowegetariańskiej w przedszkolu [Assessment of the nutrition of children following a lacto-ovo-vegetarian diet in kindergarten]. Nowa Pediatr 2016; 20(1):26-30 (in Polish)

14. Śliwińska A., Olszówka M., Pieszko M.: Ocena wiedzy na temat diet wegetariańskich wśród populacji trójmiejskiej. [Assessment of knowledge about vegetarian diets among the population of Gdańsk, Gdynia, Sopot]. Zeszyty naukowe Akademii Morskiej w Gdyni 2014, 86

15. Charzewska J., Weker H.: Ogólnopolskie badanie nad zawartością wapnia i witaminy $\mathrm{D} w$ dietach dzieci $\mathrm{w}$ wieku 4 lat. [National study on the content of calcium and vitamin $\mathrm{D}$ in diets of children aged 4 years]. Pediatria Współczesna 2006;8(2):107-109 (in Polish)

16. Wolnicka K.: Zalecenia dotyczące wartości odżywczej posiłków przedszkolnych, [Recommendations on the nutritional value of preschool meals]. In: Charzewska $J$. (ed.): Jadłospisy dla dzieci w wieku przedszkolnym (śniadania, obiady, podwieczorki) opracowane zgodnie $\mathrm{z}$ zasadami prawidłowego żywienia, Wydawnictwo IŻŻ, Warszawa 2011.

Received: 12.12 .2020

Accepted: 10.02 .2021 